\title{
Ewes carrying the Booroola and Vacaria prolificacy alleles respond differently to ovulation induction with equine chorionic gonadotrophin
}

\author{
J.C.F. Moraes and C.J.H. Souza \\ Embrapa Pecuária Sul, Bagé, RS, Brazil \\ Corresponding author: J.C.F. Moraes \\ E-mail: jose.ferrugem-moraes@embrapa.br \\ Genet. Mol. Res. 16 (3): gmr16039787 \\ Received July 28, 2017 \\ Accepted August 17, 2017 \\ Published September 21, 2017 \\ DOI http://dx.doi.org/10.4238/gmr16039787
}

Copyright $(2017$ The Authors. This is an open-access article distributed under the terms of the Creative Commons Attribution ShareAlike (CC BY-SA) 4.0 License.

\begin{abstract}
The magnitude of ovulation rate (OR) after hormonal induction in sheep should be considered when prolific genotypes are used. We investigated for the first time the effect of the Vacaria allele and its combined effect with the Booroola prolificacy mutation on OR after hormonal treatment during breeding and anoestrous season. A hundred forty-nine Ile de France crossbred ewes, raised in natural pastures in South Brazil, were used to evaluate the OR after treatment with progestagen (MAP) followed or not by equine chorionic gonadotrophin (eCG) treatment (MAP + eCG). During the breeding season, 96\% MAP-treated ewes ovulated in comparison to $97 \%$ of MAP + eCGtreated females. The double heterozygous carriers (BNVN) presented the higher OR, followed by the single Vacaria (NNVN) and Booroola (BNNN) heterozygous females and least the wild-type (NNNN) ewes. During anoestrus, 96\% eCG-treated ewes ovulated, in contrast to $6 \%$ treated with MAP alone. The OR of the gonadotrophin-treated females was higher in BNVN and BNNN than NNVN and NNNN ewes. An
\end{abstract}


additive effect in the OR of the two mutations was observed since OR in double heterozygous ewes was similar to the sum of the effects of the alleles of the single heterozygous carrier ewes.

Key words: Prolificacy; Major genes; Breeding strategies

\section{INTRODUCTION}

Nowadays, several major genes have been identified as prolificacy determinants, leading to an important understanding of ovarian function (Juengel et al., 2013). However, their usability remains to be evaluated in distinct production systems.

The identification of the GDF9 SNP called Vacaria: c943C $>\mathrm{T}$ in prolific Ile de France ewes raised in southern Brazil (Souza et al., 2014) provided a singular opportunity to investigate the effects on reproductive biology associated with Booroola mutation in the same flock, including single and double heterozygous ewes for both polymorphisms. This peculiar flock motivated the interest in quantifying the ovulatory response after an exogenous gonadotropin challenge, as background to future development of intensive out-of-season breeding systems, in flocks segregating these mutations.

An injection of equine chorionic gonadotrophin $(\mathrm{eCG})$ in prolific sheep induces higher ovulatory rates (OR) regardless the causal determinant mechanism of prolificacy: polygenic or due to single dominant genes (Driancourt, 1987; Quirke et al., 1987). The first hormonal treatments in ewes carrying the Booroola allele were performed in early 80-90 years when genotypes were estimated by female ovulation rates (Kelly et al., 1983/1984), agreeing with an additive effect of gonadotrophins on OR in Booroola genotypes (Souza et al., 1994).

The aim of this study was to investigate the ovarian response to eCG induction in Vacaria, Booroola and double heterozygous ewes, in comparison with wild-type females during the breeding season and the seasonal anoestrus at the $31^{\circ} \mathrm{S}$ latitude regions.

\section{MATERIAL AND METHODS}

\section{Animals and genotyping}

A total of 149 adult Ile de France crossbred ewes, raised in natural pastures at Embrapa Pecuária Sul Research Centre, Bagé, Rio Grande do Sul, Brazil (31¹9'50”S; 5359'30”W), were used to investigate ovulation rate after eCG hormonal induction during breeding and anoestrous seasons. These females differ with respect their genotypes for Vacaria and Booroola alleles, being: single heterozygous Vacaria (NNVN); single heterozygous Booroola (BNNN); double heterozygous (BNVN); and not carrying either allele (NNNN). The genotype determination of these ewes was made on genomic DNA extracted from white blood cells (Miller et al., 1988). The tetra-primer ARMS-PCR methodology (Ye et al., 2001) was used to classify for the Vacaria mutation (Souza et al., 2014), and a new assay was developed for the Booroola locus. Specific primers were designed with the PRIMER1 online software (http://primer1. soton.ac.uk/primer1.html) using the BMPR1b genomic sequence as a template. PCR amplification was performed in reactions containing $100 \mathrm{ng}$ genomic DNA, $2.5 \mu \mathrm{L} 10 \mathrm{X}$ buffer $(100$ mM Tris- $\mathrm{HCl}, \mathrm{pH} 8.5,500 \mathrm{mM} \mathrm{KCl}$ ), $200 \mathrm{mM}$ dNTPs, $1.5 \mathrm{mM} \mathrm{MgCl}, 25 \mathrm{pM}$ inner primers: FIP (G allele) 5'-CAGCTGGTTCCGAGAGACAGAAATATAGCG-3' and RIP (A allele)

Genetics and Molecular Research 16 (3): gmr16039787 
5'-GTTTTCATGCCTCATCAACACCGGCT-3', 2.5 pM outer primers: FOP 5'-GATGGTGAA ACAGATTGGAAAAGGTCGC-3' and ROP 5'-TAGGCAAAAACGTGCTCCTTCAAATCC C-3', 1 U Taq DNA polymerase (Ludwig Biotecnologia Ltda), and sterile water to bring total volume to $25 \mu \mathrm{L}$. PCR conditions were as follows: denaturation at $95^{\circ} \mathrm{C}$ for 2 min followed by 30 cycles of denaturation $95^{\circ} \mathrm{C}$ for $20 \mathrm{~s}$, annealing at $68^{\circ} \mathrm{C}$ for $20 \mathrm{~s}$, extension at $72^{\circ} \mathrm{C}$ for $30 \mathrm{~s}$ and the final extension at $72^{\circ} \mathrm{C}$ for $3 \mathrm{~min}$. The resulting amplicons were resolved on a $1.5 \%$ agarose gel, with the size of 157 base pairs for the A allele (N), $270 \mathrm{bp}$ for the variant $\mathrm{G}$ allele (B) and $372 \mathrm{bp}$ for the external control primers.

All animal procedures agree with the Ethical Brazilian Standards, being the animals treated during the second experiment (anoestrous season) sent to an abattoir to collect the ovulation data and morphological qualification of genital organs.

\section{Breeding season procedures}

During the local breeding season (March-April), the effects of eCG treatment on ewes carrying both prolificacy alleles were examined. To study these effects, the number of available ewes from each genotype was 39 (BNNN), 37 (NNVN), 34 (BNVN) and 39 (NNNN), proportionally represented by two- $(27 \%)$, three- $(50 \%)$ and four-year old ewes (23\%). The sampled animals were evenly distributed in the treatments [medroxyprogesterone acetate (MAP) + eCG or MAP] with respect to their genotypes and ages. The planned sample size assures at least 15 animals per group, attending a standard deviation of 1.1, for a detectable difference of 1.2 in OR, with a power of $80 \%$ and $\mathrm{P}<0.05$.

In the treated group (MAP $+\mathrm{eCG}$ ), 76 sheep received impregnated pessaries with $50 \mathrm{mg}$ MAP for 12 days and an additional injection of $500 \mathrm{IU}$ eCG at pessary withdrawal. The MAP group comprised of 73 ewes only received progestagen impregnated pessaries for 12 days. At the ninth day after the removal of pessaries, the sheep were placed in fasting during at least twelve hours and underwent exploratory laparoscopy after analgesia and local anaesthesia to check OR (Thimonier and Pelletier, 1969).

Simple comparison of the response between hormonal treatments was done by the chi-square test. The dependent variable measured were the counted number of ovulations per ewe (OR), including not ovulated ewes as zero. To attend normal distribution assumptions the data were transformed to $\log (10)$. The independent variables assigned in the model were the treatment of gonadotrophin after progestagen supplementation (MAP + eCG and MAP), the ewe genotypes (BNNN, NNVN, BNVN, and NNNN), and their interaction. OR was submitted to standard ANOVA procedures using the Psych package in the R Platform (R Core Team, 2016; Revelle, 2015). The Levene test was applied to investigate the homogeneity of variances, and the Tukey test was used to mean comparisons.

\section{Out-of-season breeding procedures}

During the period of deepest seasonal anoestrus (September and October), 104 ewes were treated with progestagen as previously described for the breeding season. In the MAP + eCG group, 51 sheep received impregnated pessaries with $50 \mathrm{mg}$ MAP for 12 days and an additional injection of $500 \mathrm{IU}$ eCG at pessary withdrawal. The MAP comprised of 53 ewes received only the progestagen-impregnated sponges for 12 days. The minimum sample per group was eight ewes, attending a standard deviation of 2.0 and a detectable difference of 3.0

Genetics and Molecular Research 16 (3): gmr16039787 
in OR during anoestrous, with a power of $80 \%$ and $\mathrm{P}<0.05$. At the ninth day after the removal of the pessaries, all ewes were slaughtered in a commercial abattoir to recover the genitalia and record reproductive traits. This procedure was chosen considering the end of the use of the experimental ewes in this study. For that reason, the ovulatory response was evaluated by visually counting the number of follicles and corpora lutea displayed on the surface of the ovaries. The follicles were classed in large follicles, with an estimated diameter greater than 5 $\mathrm{mm}$, and small follicles, with a diameter less than $5 \mathrm{~mm}$. The genitalia, sectioned in the caudal portion of the vagina, had its weight measured on a digital scale. In sequence, both ovaries were removed and individually weighed.

The procedures for statistical analysis were similar to those described for the breeding season, except for variables related to the post-mortem weight of genitalia that do not need any further transformation to attend the assumptions of ANOVA.

\section{RESULTS}

\section{Breeding season}

As expected, during the breeding season, 144 in 149 studied ewes ovulated after hormonal treatments, being $96 \%(70 / 73)$ among the females that did not receive eCG after MAP, and 97\% (74/76) of the ewes treated with MAP and eCG. The simple comparison between treatments reveals a similar response in terms of the percentage of ovulated ewes $\left(\chi^{2}\right.$ $=0.006 ;$ d.f. $=1 ; \mathrm{P}>0.05)$.

The ANOVA of the OR (logarithm transformed) reveals a significant effect of the treatment with eCG $(\mathrm{F}=27.384 ; \mathrm{P}<0.001)$ and, also a significant effect of genotypes $(\mathrm{F}=$ 9.831; $\mathrm{P}<0.001)$. No interaction was observed between treatment and tested genotypes ( $\mathrm{F}$ $=1.135 ; \mathrm{P}>0.05)$. The eCG-treated sheep presented a superiority of around $55 \%$ in back transformed values of OR compared to those treated with MAP alone (Table 1). The averages differed significantly among genotypes, indicating that the non-carrier ewes (NNNN) had the lowest OR, and the double heterozygous females (BNVN) the highest, while both heterozygotes had an OR similar between them.

Table 1. Ovulation rate of ewes after hormonal treatments among genotypes for the Vacaria and Booroola alleles during the breeding season in South Brazil (March-April).

\begin{tabular}{l|c|c|c}
\hline Treatment/Genotypes & No. of ewes & $\log (10)$ of OR $(m e a n \pm$ SE $)$ & Mean of OR $^{\#}$ \\
\hline Treatment & & & 1.74 \\
\hline MAP & 73 & $0.24 \pm 0.03^{\mathrm{a}}$ & 2.69 \\
\hline MAP + eCG & 76 & $0.43 \pm 0.03^{\mathrm{b}}$ & 1.58 \\
\hline Genotypes & 39 & & 2.09 \\
\hline NNNN & 37 & $0.20 \pm 0.03^{\mathrm{a}}$ & 2.34 \\
\hline NNVN & 39 & $0.32 \pm 0.04^{\mathrm{b}}$ & 2.95 \\
\hline BNNN & 34 & $0.37 \pm 0.04^{\mathrm{b}}$ & \\
\hline BNVN & & $0.47 \pm 0.05^{\mathrm{c}}$ & \\
\hline
\end{tabular}

"Back-transformed values. Different letters in columns mean $\mathrm{P}>0.05$.

Figure 1 presents the simple effect of the genotypes in both experimental conditions. This bar graph shows the contrast of means between non-carrier ewes and single and double heterozygous ewes studied during the breeding season. For instance, in the MAP group, the OR means of BNNN and BNVN differs significantly from non-carrier ewes. In MAP + eCG group, only the OR means of double heterozygous ewes differs from NNNN.

Genetics and Molecular Research 16 (3): gmr16039787 


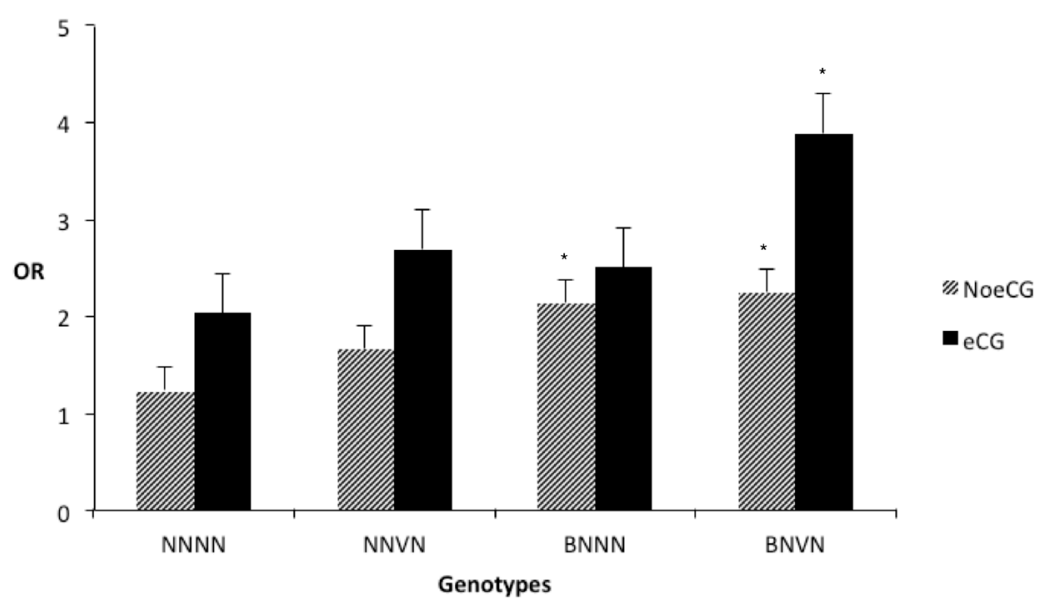

Figure 1. Means of ovulation rate during the breeding season for the investigated genotypes treated or not with eCG. *Significant difference from NNNN genotypes $(\mathrm{P}<0.05)$.

The estimated effect of the presence of the Vacaria and Booroola allele could be due to subtracting the OR of the wild genotype ewes (NNNN) from the OR of each carrier genotype in MAP group. Using the back transformed values presented in Table 1, the effect in OR is 0.51 for the NNVN, 0.76 for the BNNN and 1.37 for the BNVN females. The sum of the effects in the heterozygous carriers represents $93 \%$ of the calculated effect on the OR in BNVN ewes.

\section{Out of season}

Concerning the ovarian response, the frequency of ovulated ewes is $6 \%(3 / 49)$ in non-treated females, and 96\% (44/46) in eCG-treated ewes $\left(\chi^{2}=72.541\right.$; d.f. $=1$; $\left.\mathrm{P}<0.001\right)$. Within the MAP group, one BNVN and two NNVN ewes presented corpora lutea in their ovaries, and among the MAP + eCG group only two BNNN ewes did not ovulate.

The analysis of variance of OR revealed significant effects due to eCG treatment $(\mathrm{F}=9.184 ; \mathrm{P}<0.01)$ and genotypes $(\mathrm{F}=5.174 ; \mathrm{P}<0.01)$. Also, no significant interaction was observed between treatment and tested genotypes $(\mathrm{F}=0.039 ; \mathrm{P}>0.05)$. The observed means of OR in the group that did not receive the gonadotrophin (MAP) was very nearly to null, whereas the treated ewes showed a magnitude of OR quite similar to the observed during breeding season (Table 2). The OR of the non-carrier ewes was similar to the Vacaria heterozygous females and lower than the Booroola heterozygous (BNNN) and double heterozygous (BNVN).

During the out-of-season evaluation, we can also observe that the sum of the effects in the heterozygous carriers represented $74 \%$ of the calculated effect of the BNVN ewes. The effect of genotype in the OR was 0.35 for the NNVN, 1.40 for the BNNN and 2.38 for the BNVN females.

The simple effect of genotypes is shown in Figure 2. This bar graph illustrates the need of the equine gonadotrophin to induce ovulation during anoestrous, and that in the eCG-treated group OR only differs significantly between BNVN and NNNN ewes. The single heterozygous carriers of Vacaria and Booroola alleles showed similar intermediary values for OR. 
Table 2. Ovulation rate of ewes after hormonal treatments among genotypes for the Vacaria and Booroola alleles during anoestrous season in South Brazil (September-October).

\begin{tabular}{l|c|c|c}
\hline Treatment/Genotypes & No. of ewes & $\log (10)$ OR $($ mean \pm SE) & Mean of OR $^{\#}$ \\
\hline Treatment & & & 1.26 \\
\hline MAP & 49 & $0.10 \pm 0.01^{\mathrm{a}}$ & 2.88 \\
\hline MAP +eCG & 46 & $0.46 \pm 0.04^{\mathrm{b}}$ & 1.99 \\
\hline Genotypes & & & 2.34 \\
\hline NNNN & 27 & $0.30 \pm 0.05^{\mathrm{a}}$ & 3.39 \\
\hline NNVN & 24 & $0.37 \pm 0.08^{\mathrm{a}}$ & 4.37 \\
\hline BNNN & 28 & $0.53 \pm 0.04^{\mathrm{b}}$ & \\
\hline BNVN & 16 & $0.64 \pm 0.10^{\mathrm{b}}$ & \\
\hline
\end{tabular}

\#Back-transformed values. Different letters in columns mean $(\mathrm{P}>0.05)$.

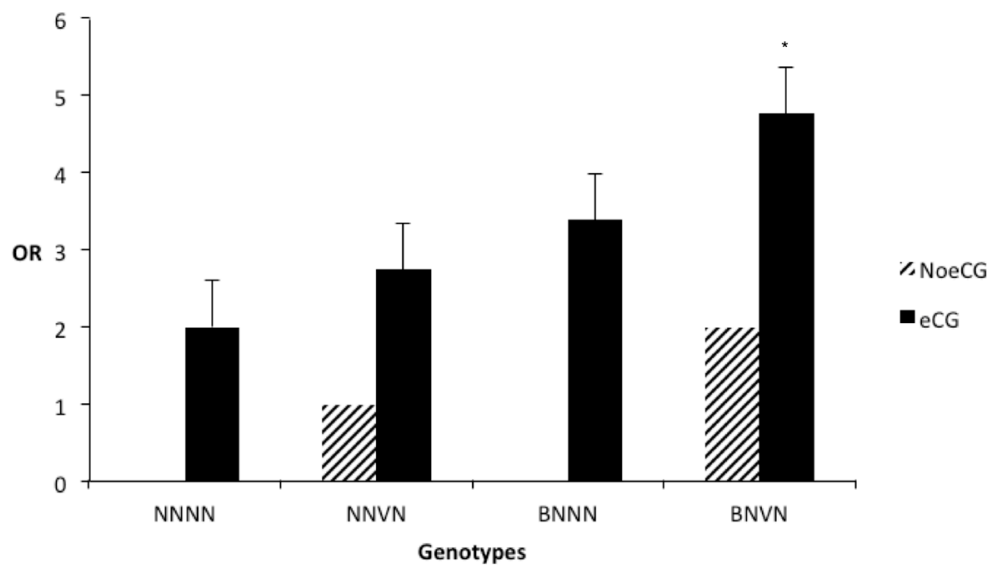

Figure 2. Means of ovulation rate during the anoestrous season for the investigated genotypes treated or not with eCG. *Significant difference from NNNN genotypes $(\mathrm{P}<0.05)$.

The genitalia of the studied ewes showed an overall average weight of the $65.11 \pm$ $1.65 \mathrm{~g}$, and their ovaries weights $2.34 \pm 0.12 \mathrm{~g}$, with a mean of $2.78 \pm 0.22$ of large follicles and $14.35 \pm 0.64$ of small follicles in both ovaries of each female, ranging from $0-9$ large follicles, and from 2-35 small follicles. All means observed in both treatments and genotypes are shown in Table 3. The weight of genitalia $(\mathrm{F}=68.479 ; \mathrm{P}<0.001)$ and ovaries $(\mathrm{F}=79.286$; $\mathrm{P}<0.001)$ were different between treatments but similar among genotypes, also without any significant interaction between them. In addition, the number of large and small follicles was affected by neither treatments nor genotypes $(\mathrm{P}>0.05)$.

Table 3. Average weight of the genitals and ovaries, the number of large and small follicles in the gonads of the ewes of different genotypes, treated or not with eCG during seasonal anoestrus (September-October).

\begin{tabular}{l|c|c|c|c}
\hline Treatment/Genotypes & Genital weight $(\mathrm{g})$ & Ovary weight $(\mathrm{g})$ & No. of large follicles & No. of small follicles \\
\hline Treatment & & & & \\
\hline MAP & $54.74 \pm 1.67^{\mathrm{b}}$ & $1.60 \pm 0.08^{\mathrm{b}}$ & $3.10 \pm 0.34$ & $13.94 \pm 0.75$ \\
\hline MAP +eCG & $75.90 \pm 1.88^{\mathrm{a}}$ & $3.15 \pm 0.16^{\mathrm{a}}$ & $2.43 \pm 0.28$ & $14.78 \pm 1.05$ \\
\hline Genotype & & & & \\
\hline NNNN & $63.13 \pm 2.71$ & $2.64 \pm 0.19$ & $3.48 \pm 0.37$ & $14.63 \pm 1.18$ \\
\hline NNVN & $68.34 \pm 3.37$ & $2.47 \pm 0.26$ & $2.62 \pm 0.38$ & $13.33 \pm 1.23$ \\
\hline BNNN & $64.72 \pm 3.24$ & $2.13 \pm 0.24$ & $2.39 \pm 0.39$ & $13.36 \pm 1.00$ \\
\hline BNVN & $64.56 \pm 4.38$ & $2.02 \pm 0.24$ & $2.50 \pm 0.76$ & $17.12 \pm 1.88$ \\
\hline
\end{tabular}

Different letters in columns mean $\mathrm{P}<0.05$. 


\section{DISCUSSION}

The first result of this essay is the non-significant interaction between treatment and genotypes, highlighting that the increased $55 \%$ in OR during breeding season after eCG treatment is additive to the expected differences among genotypes. Also, the data collected reiterates the higher OR in NNVN and BNNN than NNNN ewes, due the presence of one copy of both studied target alleles (Juengel et al., 2013; Souza et al., 2014), and the highest OR in the double heterozygous ewes, illustrating the combined effect of the both major genes (Table 1). A secondary result was that it is reasonable to recommend no need of eCG treatment at least for Booroola heterozygous ewes during the breeding season, since these animals showed higher OR than wild-type ewes (Figure 1), whereas in eCG-treated sheep just BNVN females presented the highest frequency of ovulation rate.

The main result of this study is the report of the combined effect of Booroola and Vacaria mutations. Double heterozygous sheep showed an apparent additive effect on OR compared to each single heterozygous group. In both breeding season and seasonal anoestrus, the ORs of each mutation carriers were higher than non-carriers and lower than the observed in the double heterozygous ewes, only in module or statistically, but the sum of effects of the single heterozygous mutations was almost similar to the OR observed in the double heterozygous eCG-treated sheep. This result differs from the Inverdale and Booroola heterozygous sheep reported by Davis et al. (1999), who found higher OR in the double heterozygous animals than the sum of each mutation, suggesting a multiplicative effect. A possible explanation for the additive effect observed in the Vacaria Booroola double heterozygote ewes could be due to the action of two genes, BMPR1B and GDF9, located on different chromosomes, and the fact that GDF9 ligand does not use the receptor of BMPR1B for its signalling pathway (Souza et al., 2007).

During anoestrus, most of eCG-untreated ewes did not ovulate, regardless of genotype. Considering the effects of treatment and genotypes, we can infer that the presence of the Vacaria mutation did not positively affect OR (Table 2). And, also regarding the simple effect of genotypes when treated with eCG, the presence of these alleles (Vacaria or Booroola) do not promote higher OR than observed in NNNN ewes (Figure 2).

Taken together, these data reiterate the increased number of ovulations in the single heterozygous carriers for both mutations after eCG treatment. Therefore, oestrous synchronisation protocols must be carefully planned during out of season, when gonadotrophin is essential to avoid high percentages of $>3 \mathrm{OR}$. Further studies should be necessary, since Lahoz et al. (2011) observed significant interactions among age, genotypes and eCG doses after ovulation induction in prolific heterozygous ewes carrying a deletion in BMP15.

The prevalence of these double heterozygous in commercial flocks should be very rare, depending on the presence and/or the introduction of both major genes. The highest number of ovulations in these ewes may be not useful in intensive lamb production systems, because there are some preliminary evidences of in utero losses by BNVN ewes (Souza and Moraes, 2014).

The biometry of the reproductive organs in our study was not affected by the genotypes of the ewes. The higher averages of genital and ovary weights in eCG-treated ewes could be related to the hormonal stimulation in reproductive tissues (Table 3). Regarding the increase in ovary weight it could be attribute to the presence of the corpora lutea in the gonadotrophintreated ewes, since there are no differences in follicle populations between the groups.

Genetics and Molecular Research 16 (3): gmr16039787 


\section{CONCLUSION}

The combined effect of Vacaria and Booroola mutations could be assumed to be additive since the OR of the double heterozygous ewes was roughly similar to the sum of the effect of each allele on the OR of single heterozygous carrier ewes. Ovulation induction during breeding season was obtained without eCG treatment regardless of genotype, contrasting with the compulsory need of this hormone to induce ovulation in the non-breeding season. During breeding season, the higher ovulation rate observed in single heterozygous carriers indicates that oestrous synchronization plans could be implemented without the aid of the equine gonadotrophin.

\section{ACKNOWLEDGMENTS}

We are grateful to Dr Lígia Pegoraro and her graduate student Felipe Terres de Campos for their assistance with sample collection and evaluation of ovaries during the out of season experiment, and to Dr Magda Vieira Benavides for reviewing the manuscript.

\section{REFERENCES}

Davis GH, Dodds KG and Bruce GD (1999). Combined effect of the Inverdale and Booroola prolificacy genes on ovulation rate in sheep. Proc. Assoc. Advmt. Anim. Breed. Genet. 13: 74-77.

Driancourt MA (1987). Ovarian features contributing to the variability of PMSG-induced ovulation rate in sheep. $J$. Reprod. Fertil. 80: 207-212. https://doi.org/10.1530/jrf.0.0800207

Juengel JL, Davis GH and McNatty KP (2013). Using sheep lines with mutations in single genes to better understand ovarian function. Reproduction 146: R111-R123. https://doi.org/10.1530/REP-12-0509

Kelly RW, Owens JL, Crosbie SF, McNatty KP, et al. (1983/1984). Influence of Booroola Merino genotype on the responsiveness of ewes to pregnant mares serum gonadotrophin, luteal tissue weights and peripheral progesterone concentrations. Anim. Reprod. Sci. 6: 199-207. https://doi.org/10.1016/0378-4320(83)90038-6

Lahoz B, Alabart JL, Jurado JJ, Calvo JH, et al. (2011). Effect of the FecX(R) polymorphism in the bone morphogenetic protein 15 gene on natural or equine chorionic gonadotropin-induced ovulation rate and litter size in Rasa Aragonesa ewes and implications for on-farm application. J. Anim. Sci. 89: 3522-3530. https://doi.org/10.2527/jas.2010-3828

Miller SA, Dykes DD and Polesky HF (1988). A simple salting out procedure for extracting DNA from human nucleated cells. Nucleic Acids Res. 16: 1215. https://doi.org/10.1093/nar/16.3.1215

Quirke JF, Meyer HH, Lahlou-Kassi A, Hanrahan JP, et al. (1987). Natural and induced ovulation rate in prolific and non-prolific breeds of sheep in Ireland, Morocco and New Zealand. J. Reprod. Fertil. 81: 309-316. https://doi. org/10.1530/jrf.0.0810309

R Core Team (2016). R: A language and environment for statistical computing. R Foundation for Statistical Computing, Vienna, Austria. Available at [https://www.R-project.org/].

Revelle W (2015). psych: Procedures for Personality and Psychological Research, Northwestern University, Evanston, Illinois, USA. Available at [http://CRAN.R-project.org/package $=$ psych Version $=1.5 .8]$.

Souza CJH and Moraes JCF (2014). Recomendações para o uso de alelos determinantes de prolificidade em ovinos. Embrapa Pecuária Sul, Bagé. Comunicado Técnico. 88: 1-3.

Souza CJH, Moraes JCF and Chagas LM (1994). Effect of the Booroola gene on time of ovulation and ovulatory dynamics. Anim. Reprod. Sci. 37: 7-13. https://doi.org/10.1016/0378-4320(94)01324-1

Souza CJH, Melo EO, Moraes JCF and Baird DT (2007). Role of bone morphogenetic proteins in follicle development. In: Novel Concepts in Ovarian Endocrinology (Gonzalez-Bulnes A, ed.). Transworld Research Network, Trivandrun.

Souza CJH, McNeilly AS, Benavides MV, Melo EO, et al. (2014). Mutation in the protease cleavage site of GDF9 increases ovulation rate and litter size in heterozygous ewes and causes infertility in homozygous ewes. Anim. Genet. 45: 732-739. https://doi.org/10.1111/age.12190

Thimonier J and Pelletier J (1969). Différence génétique dans la décharge ovulant (LH) chez des brebis de race Ile de France; relations avec le nombre d'ovulations. Ann. Biol. Anim. Biochim. Biophys. 6: 559-567.

Ye S, Dhillon S, Ke X, Collins AR, et al. (2001). An efficient procedure for genotyping single nucleotide polymorphisms. Nucleic Acids Res. 29: E88-E8. https://doi.org/10.1093/nar/29.17.e88

Genetics and Molecular Research 16 (3): gmr16039787 